\title{
PENERAPAN MANAJEMEN PROGRAM ODF DI PUSKESMAS SIDOARJO KABUPATEN SIDOARJO TAHUN 2019
}

Aisyah Putri Tauladani, Hadi Suryono, Setiawan Jurusan Kesehatan Lingkungan Poltekkes Kemenkes Surabaya Email: Aisyah18tauladani@gmail.com

\begin{abstract}
ABSTRAK
Manajemen adalah proses yang terdiri dari perencanaan, pengorganisasian, pelaksanaan, dan pengawasan untuk mencapai sasaran atau tujuan secara efektif dalam pencapaian melalui penyelenggaraan yang dilaksanakan dengan baik dan benar serta bermutu, berdasarkan atas hasil analisis situasi yang didukung dengan data dan informasi yang akurat dan efisien sebagai memanfaatkan sumber daya yang tersedia. Penelitian ini bertujuan untuk mengetahui penerapan manajemen program ODF yang dilaksanakan Puskesmas agar tercapai target kinerja dalam peningkatan program.

Penelitian ini merupakan penelitian deskriptif dengan pendekatan cross sectional. Objek penelitian adalah manajemen pelaksanaan program kesehatan lingkungan terhdap desa yang belum ODF. Subyek penelitian ini adalah responden yang terdiri dari pimpinan Puskesmas, tenaga kesehatan lingkungan dan tenaga lain yang terlibat dalam pengelolaan kesehatan lingkungan. Teknik pengumpulan data dilaksanakan dengan kuisioner dan wawancara.

Hasil Puskesmas Sidoarjo sudah baik dalam melaksanakan program ODF. Hasil dari fungsi manajemen program ODF untuk observasi mendapatkan nilai $85,4 \%$ dan wawancara mendapatkan nilai $72,5 \%$. Hasil rekapitulasi berdasarkan tingkat ekonomi di dua desa mendapatkan nilai 59,09\% dan 48,03\%, untuk tingkat pendidikan di dua desa mendapatkan nilai $36 \%$ dan $43 \%$, tingkat pengetahuan dari dua desa mendapatkan nilai $56 \%$ dan $41 \%$.

Kesimpulannya, hasil dari manajemen di puskesmas mendapatkan hasil baik dan hasil dari masyarakat mendapatkan hasil cukup baik. Disarankan untuk masyarakat untuk mencari informasi tentang STBM dan bekerjasama dengan fasilitator desa dan pemerintah.
\end{abstract}

Kata Kunci : Manajemen, Program ODF

\section{PENDAHULUAN}

Manajemen adalah proses yang terdiri dari perencanaan, pengorganisasian, pelaksanaan, dan pengawasan untuk mencapai sasaran atau tujuan secara efektif dalam pencapaian melalui penyelenggaraan yang dilaksanakan dengan baik dan benar serta bermutu, berdasarkan atas hasil analisis situasi yang didukung dengan data dan informasi yang akurat dan efisien sebagai memanfaatkan sumber daya yang tersedia untuk dapat melaksanakan upaya kesehatan sesuai standar dengan baik dan benar, sehingga dapat mewujudkan target kinerja yang telah ditetapkan (Peraturan Menteri Kesehatan Nomor 44 Tahun 2016).

Kesehatan lingkungan merupakan upaya pencegahan penyakit atau gangguan kesehatan dari factor risiko lingkungan untuk mewujudkan kualitas lingkungan yang sehat baik dari aspek baik, kimia, biologi dan social. Menurut Kepmenkes RI No. 1428 tahun 2006, pengawasan kesehatan lingkungan merupakan bagian dari mempertahankan dan meningkatkan kualitas lingkungan yang lebih baik dan bermanfaat bagi manusia. Perbaikan kualitas lingkungan tidak hanya dilaksanakan diluar tetapi juga didalam lingkungan puskesmas.

Di dalam surat keluaran Peraturan Kementerian Kesehatan (2014), STBM terdiri atas 5 pilar, utama yaitu Stop buang air besar sembarangan, Cuci tangan pakai sabun (CTPS), Pengelolaan air minum dan makanan yang aman, Pengelolaan sampah rumah tangga, dan Pengelolaan limbah cair rumah tangga. Dari kelima pilar dalam program STBM tersebut, pilar pertama yaitu Stop buang air besar sembarangan yang sangat 
berpengaruh terhadap kesehatan masyarakat, karena lingkungan yang akan berdampak luas terhadap masyarakat sekitar.

Tujuan dari penelitian ini adalah untuk mengetahui penerapan manajemen program ODF yang dilaksanakan di Puskesmas Sidoarjo Kabupaten Sidoarjo Tahun 2019 serta menganalisis factor pengetahuan dari program ODF.

\section{METODE PENELITIAN}

Penelitian ini merupakan penelitian deskriptif dengan pendekatan cross sectional. Jumlah responden dari petugas kesehatan sebanyak 10 orang dan responden dari 2 desa yaitu sebesar 110 orang dan 93 orang.

Variable terikat Dalam penelitian ini adalah kualitas hasil dari pencapaian penerapan manajemen kesehatan lingkungan di puskesmas. Variabel bebasnya adalah Penerapan manajemen terhadap desa yang belum ODF, Penerapan manajemen berdasarkan tingkat ekonomi, Penerapan manajemen berdasarkan tingkat pendidikan dan Penerapan manajemen berdasarkan tingkat pengetahuan.

Teknik pengumpulan data dilaksanakan dengan kuisioner dan wawancara. Teknik pengolahan data menggunakan editing, coding, dan tabulasi. Analisis data dilakukan objektif secara deskriptif yaitu menggambarkan obyek yang diteliti dengan tabel hasil data yang diperoleh dalam manajemen kesehatan lingkungan di Puskesmas.

\section{HASIL DAN PEMBAHASAN}

Total Penerapan Manajemen untuk Petugas Kesehatan

Tabel 1

TOTAL PENERAPAN MANAJEMEN DI PUSKESMAS SIDOARJO KABUPATEN SIDOARJO TAHUN 2019

\begin{tabular}{llcc}
\hline NO & Fungsi - fungsi Manajemen & Observasi & Wawancara \\
\hline 1. & Perencanaan & 3 & 22 \\
\hline 2. & Pengorganisasian & 2 & 15 \\
\hline 3. & Pelaksanaan & 3 & 31 \\
\hline 4. & Pengawasan & 5 & 44 \\
\hline \multirow{2}{*}{ Total } & 13 & 112 \\
\cline { 3 - 4 } & & $85,4 \%$ & $72,5 \%$ \\
\cline { 3 - 4 } & & Baik & Baik \\
\hline
\end{tabular}

\section{Perencanaan}

Penelitian ini berisi tentang perencanaan program kegiatan desa yang belum ODF dengan mengetahui tindakan yang dilakukan petugas kesehatan lingkungan dalam menyusun. Penyusunan dilakukan untuk mengetahui kegiatan yang direncanakan dalam program kinerja pada lapangan.

Berdasarkan tabel 1 tentang Perencanaan Penerapan Manajemen di Puskesmas Sidoarjo Kabupaten Sidoarjo tahun 2019 mendapatkan hasil observasi baik yaitu sebesar $100 \%$, dan wawancara mendapatkan hasil baik yaitu sebesar $72 \%$.
Hasil rekapitulasi mengatakan bahwa petugas mengetahui pentingnya dilakukan perencanaan kegiatan yang akan dilakukan secara rinci agar tidak terjadi penumpukan dengan kegiatan yang lan. Penyusunan rencana kerja dilakukan secara terbuka oleh tenaga kerja yang akan dilakukan.

\section{Pengorganisasian}

Penelitian ini berisi tentang pengorganisasian yang dijalankan dalam kegiatan desa yang belum ODF dimana kegiatan ini harus pendekatan langsung kedalam masyarakat agar dapat mengetahui permasalahan yang ada. 
Pendekatan tidak dilakukan dalam waktu bersamaan oleh petugas kesehatan lingkungan tetapi dengan bantuan petugas kesehatan lain yang berada di desa maka kegiatan dapat dibagi kemudian dilakukan pemantauan langsung ke lapangan.

Berdasarkan Tabel 1 tentang Pengorganisasian Penerapan Manajemen dapat diketahui bahwa di Puskesmas Sidoarjo Kabupaten Sidoarjo Tahun 2019 mendapatkan hasil observasi cukup baik yaitu sebesar $66,7 \%$ dan hasil wawancara mendapatkan hasil cukup baik yatu sebesar $50 \%$. Pengorganisasian harus dilakukan dengan membagi tugas dalam perencanaan agar membentuk kesatuan sehingga dapat dipertanggungjawabkan.

\section{Pelaksanaan}

Berdasarkan tabel 1 tentang pelaksanaan Penerapan Manajemen di Puskesmas Sidoarjo tahun 2019 mendapatkan hasil observasi dan wawancara baik yaitu sebesar $75 \%$. Pelaksanaan merupakan realisasi yang dilakukan dalam perencanaan agar dapat tercapai sesuai tujuan.

Hasil penelitian lapangan dilakukan terdapat factor factor yang belum terlaksana secara optimal dalam program yaitu : tidak dapat terlaksananya pemicuan sesuai rencana dan jadwal yang ditentukan.

Pelaksanaan dilakukan dengan memanfaatkan komponen komponen pelaksanaan kegiatan yaitu : rencana dan jadwal yang dilakukan seharusnya dapat dijalankan sesuai dengan penyusunan dari awal. Dalam pelaksanaan belum terlaksana sesuai susunan yang dibentuk maka belum tepat dalam pembagian jam sesuai dengan kegiatan. Kegiatan yang dilakukan banyak namun jika dalam rencana dan jadwal yang sudah dibentuk maka dapat tercapai kebutuhan.

\section{Pengawasan}

Berdasarkan tabel 1 tentang Pengawasan Penerapan Manajemen di Puskesmas Sidoarjo tahun 2019 mendapatkan hasil observasi dan wawancara baik yaitu sebesar $88 \%$. Pengawasan dilakukan agar dapat meninjau kegiatan yang sudah dilakukan sesuai dengan ketentuan yang sudah ditetapkan.

Hasil penelitian lapangan dilakukan terdapat factor factor yang belum terlaksana secara optimal yaitu : tidak adanya pemantauan setiap kegiatan STBM dan tidak adanya laporan kemajuan STBM. Pengawasan merupakan salah satu pembentuk kinerja agar dapat berjalan dan kerja sama antara kepala dan staf yang melakukan kegiatan. Kerjasama yang baik akan membentuk sumber daya yang baik sehingga aktifitas pencapaian program dapat dilakukan dengan peningkatan dalam setiap kekurangan.

Total Penerapan Manajemen Program ODF Berdasarkan Tingkat Ekonomi pada desa Sidokumpul dengan jumlah masyarakat 65 orang sebesar $59.09 \%$, sedangkan Penerapan Manajemen Program ODF Berdasarkan Tingkat Ekonomi pada desa Sidoklumpuk dengan jumlah masyarakat 48 orang sebesar $48.3 \%$. Dari hasil penelitian tersebut bahwa masyarakat di desa Sidokumpul dan desa Sidoklumpuk sebanyak 59,09\% dan 48,03\% mendapatkan penghasilan sebesar Rp. 3.864.000,-. Dengan berpenghasilan tersebut, Masyarakat desa sidokumpul dan sidoklumpuk bisa memanfaatkan untuk memperbaiki kondisi jamban atau membangun septic tank agar terhindar dari penyakit yang diakibatkan oleh lingkungan disekitar.

Berdasar tingkat pendidikan, penerapan manajemen kesehatan lingkungan di desa belum ODF untuk Desa Sidokumpul didapatkan bahwa yang berpendidikan terakhir SMA sebesar 36\% dan Desa Sidoklumpuk berpendidikan terakhir SMA sebesar 43\%.

Tingkat pendidikan yang rendah akan susah mencerna pesan atau indormasi yang disampaikan. Pendidikan diperoleh melalui proses belajar yang khusus diselenggarakan pada waktu tertentu, tempat tertentu, dan kurikulum tertentu namun dapat diperoleh dari bimbingan yang diselenggarakan sewaktu waktu dengan maksud mempertinggi kemampuan atau keterampilan khusus. Berdasar tingkat pengetahuan penerapan manajemen kesehatan lingkungan terhadap desa belum ODF untuk Desa 
Sidokumpul mendapatkan hasil yang cukup baik yaitu sebesar $56 \%$ dan Desa Sidoklumpuk mendapatkan hasil yang cukup baik yaitu sebesar $41 \%$.

Tingkat pengetahuan ini berkaitan dengan tingkat ekonomi dan pendidikan, semakin tinggi penghasilan dari masyarakat itu akan semakin tinggi juga tingkat pengetahuan dan begitu juga sebaliknya. Karena jika masyarakat berpenghasilan tinggi dan berpendidikan tinggi, masyarakat akan mengetahui dan memahami tentang STBM melalui alat elektronik atau dapat dengan mudah memahami informasi yang ada. Akibat dari penggunaan jamban yang tidak sehat, bisa menimbulkan berbagai penyakit bagi masyarakat. Pengetahuan ini sangat penting bagi masyarakat karena bisa mengubah kebiasaan masyarakat dan masyarakat bisa hidup bersih dan sehat.

\section{KESIMPULAN}

Berdasarkan hasil penelitian dan pembahasan tentang Manajemen Kesehatan Lingkungan di Puskesmas Sidoarjo Kabupaten Sidoarjo dapat diambil kesimpulan sebagai berikut :

1. Total Keseluruhan Penerapan Manajemen pada Desa belum ODF berdasarkan observasi dan wawancara baik yaitu sebesar $85,4 \%$ dan $72,5 \%$. Berdasarkan penerapan manajemen di puskesmas melalui fungsi fungsi manajemen berikut ini :
a. Proses
Perencanaan mendapatkan hasil observasi dan wawancara baik yaitu sebesar $100 \%$ dan $72 \%$.

b. Proses Pengorganisasian mendapatkan hasil observasi dan wawancara cukup baik yaitu sebesar $66 \%$ dan $50 \%$.

c. Proses Pelaksanaan mendapatkan hasil observasi dan wawancara baik yaitu sebesar $75 \%$.

d. Proses Pengawasan mendapatkan hasil observasi dan wawancara baik yaitu sebesar $88 \%$.

2. Total Keseluruhan Penerapan Manajemen pada Desa belum ODF khusus untuk 2 desa yaitu Desa Sidokumpul dan Sidoklumpuk :

a. Tingkat ekonomi pada masyarakat desa sidokumpul dan sidoklumpuk tergolong berpenghasilan tinggi yaitu UMR sebesar $94 \%$.

b. Tingkat pendidikan pada masyarakat desa sidokumpul dan sidoklumpuk tergolong berpendidikan SMA yaitu 79\%.

c. Tingkat pengetahuan pada masyarakat desa sidokumpul dan sidoklumpuk yaitu cukup baik sebesar $41 \%$ dan $56 \%$.

\section{SARAN}

1. Bagi Puskesmas Sidoarjo

a. Pelaksanaan program yang dilakukan untuk membentuk tim fasilitator STBM agar kegiatan STBM lebih teratur dan sesuai dengan pedoman STBM.

b. Kegiatan Kesehatan Lingkungan dilakukan penjadwalan yang sudah disesuaikan dengan pelaksanaan dilapangan agar dapat berjalan sesuai kebutuhan dan target yang akan dicapai.Bagi Masyarakat

a. Mengikuti aktif yang dilaksanakan fasilitator STBM

b. Mencari informasi tentang STBM dan ODF

c. Bekerjasama antara fasilitator desa dengan pemerintah untuk pengetahuan masyarakat.

2. Bagi Peneliti Lain

Sebaiknya dilakukan penelitian factor - factor lain untuk pencapaian program ODF dalam manajemen puskesmas untuk meningkatkan kegiatan Kesehatan Lingkungan.

\section{DAFTAR PUSTAKA}

Agustini, 2013. (Pengelolaan dan Unsurunsur Manajemen). Jakarta: Citra Pustaka.

Chandra, budiman, 2007. Pengantar Kesehatan Lingkungan. Jakarta: Penerbit buku kedokteran EGC.

Direktorat PP dan PL, Kementerian Kesehatan.2017. Buku Saku 
Verifikasi Sanitasi Total

Berbasis Masyarakat

(STBM).Sekretariat STBM.

Hardjosoebroto, Soedinar., Soeripto, $1993 . \quad$ (Manajemen

Puskesmas). Yogyakarta, Balai Pustaka : 22, 32-34.

Mairizo., Kiswanto, 2014. (Fungsi Fungsi Manajemen Publik). Pekanbaru, Jurnal Kebijakan Publik.

Oktarina,. Sugiharto, Mugeni, 2011. (Pelaksanaan Program Kesehatan Lingkungan Puskesmas Di Kabupaten Tuban Provinsi Jawa Timur). Tuban, Buletin Penelitian Sistem kesehatan.

Peraturan Menteri Kesehatan Nomor 44
Pedoman

Manajemen

Puskesmas

Sutiyono,Shaluhiyah Zahroh,Purnama Tri

Cahya, 2014. Analisis

Pelaksanaan Program

Sanitasi Total Berbasis

Masyarakat Sebagai Strategi

Peningkatan Perilaku Hidup

Bersih dan Sehat

Masyarakat oleh Petugas

Puskesmas Kabupaten

Grobogan. Fakultas

Kesehatan Masyarakat

Universitas Diponegoro.

Trihono, 2015. (ARRIME Manajemen

Puskesmas Berbasis

Paradigma Sehat). Jakarta, Sagung Seto : 12,39

Tahun $2016 \quad$ Tentang 